\title{
PLATO’S PROTAGORAS THE HEDONIST
}

\author{
JOSH WILBURN
}

I

N THE FINAL SECTION OF Plato's Protagoras, Socrates famously invokes a version of hedonism that renders the terms "pleasant" and "good" (along with "painful" and "bad") interchangeable (353c-357e). On the basis of this hedonistic identification of pleasure and the good, Socrates confronts, first, the Many's view that knowledge is often "dragged around" by pleasure and other emotional states, and second, Protagoras' claim that courage is "entirely different" from knowledge and the rest of the virtues. Socrates' use of hedonism is noteworthy and puzzling: in this critical scene from the Protagoras, he invokes it to defend two philosophical commitments that are evidently important to him, and that Plato takes very seriously - the supremacy of knowledge and the unity of the virtues. Yet Socrates relies on hedonism in no other Platonic dialogue, and it seems even to conflict both with the views his character expresses elsewhere, as well as with Plato's own settled philosophical positions. Consequently, the issue of hedonism's precise role in the dialogue has been much discussed by commentators, with the controversy often focused on the question: To whom does the hedonism of the dialogue rightly belong? Some interpreters have argued that Socrates' endorsement of the view is sincere, and that Plato, at least in the Protagoras, deems it a position worth considering. ${ }^{1}$ Others have argued that Socrates' appeal to hedonism is entirely ad hominem: he invokes it only for the sake of argument, and only because he takes it to be the (perhaps implicit) view of his interlocutors - of the Many (the interpretation most explored and emphasized by commentators), or of Protagoras, or of both. ${ }^{2}$

1. Commentators who attribute hedonism to Socrates and/or Plato include Crombie 1962, 240-41; Dodds 1959, 21-22 n. 3; Grote 1888, 314-15; Hackforth 1928; Irwin 1977, 103; 1995, 242; Rudebursch 1989; C. C. W. Taylor 1976, 208-210; Vlastos 1956, xl n. 50. Dodds, for instance, states that "the dialogue contains no hint that the [hedonistic] assumption is made merely for the sake of argument." There are also some more nuanced versions of this line of interpretation: Bentley $(2003,94,104)$ argues that Socrates endorses only an "enlightened" form of hedonism; Guthrie $(1969,259,463)$ takes Socrates to be committed to a broader form of utilitarianism; and Dimas (2008) attributes the position advocated in the Protagoras to Socrates but denies that it amounts to hedonism.

2. Commentators who emphasize the Many's commitment to hedonism include Clark 2012, 237; Dyson 1976, 43; Ebert 2003; Frede 1992, xxviii; Klosko 1980, 312; Santas 1966, 8 n. 8; A. E. Taylor 1927, 260-61; Vlastos 1969, 76-78. Those who attribute hedonism to both the Many and Protagoras include Coby 1987, 147; Goldberg 1983, 309-10 n. 10; Grube 1933; Sesonske 1963; Sullivan 1961; Wolfsdorf 2006, 133; Zeyl 1980. Ebert (2003) also draws attention to the hedonistic character of the unnamed friend in the frame dialogue and argues convincingly that the friend is intended to be a generic representative of the democratic Many. Bentley (2003, 90 n. 14) similarly recognizes democratic tendencies in Hippocrates himself. A small number of commentators, notably Duncan (1978) and McCoy (1998), focus on Protagoras' commitment to hedonism. Ferrari $(1990,133)$, Russell $(2005,239-48)$, and Weiss $(2006,67$; cf. 1989, 520) adopt a somewhat different strategy for explaining the dialogue's hedonism: they take Plato's use of hedonism to have one or another special dialectical

Classical Philology 111 (2016): 1-21

[C 2016 by The University of Chicago. All rights reserved] 0009-837X/16/11103-0002\$10.00 
I will advocate an ad hominem reading that attributes hedonism both to the Many and to Protagoras. My focus, however, will be on the latter. I will argue that the Protagoras in various ways reflects Plato's view that the sophist is an inevitable advocate for, and himself implicitly inclined toward, hedonism, and I will attempt to show that the text aims through that characterization to undermine Protagoras' status as an educator. One of my objectives in the course of my arguments will be to explore connections between the final argument of the Protagoras and the Man-Measure Doctrine as it is developed in the Theaetetus. I will begin in Section 1 with a brief look at Socrates' cautionary conversation with Hippocrates while on their way to visit Protagoras. I will then, in Sections 2 through 4, offer three main arguments for thinking that Plato intends to portray Protagoras as a proponent of, and in sympathy with, hedonistic views in the dialogue. I will argue, first, that Protagoras' profession as a sophist requires him to espouse, and perhaps also accept, ideas that appeal to the hedonistic tendencies of the Many. My argument will be based in part on a reading of $334 \mathrm{a}-\mathrm{c}$, an important passage in which Protagoras delivers a short speech on the nature of goodness. Second, drawing on material from the Theaetetus, I will argue that the Protagoras adumbrates what Plato takes to be hedonistic implications of Protagoras' own Man-Measure doctrine. Third, I will argue that Plato's depiction of Protagoras' own character emphasizes the sorts of pleasure-oriented, appetitive tendencies and concerns that Plato associates with hedonistic values. In Sections 5 and 6, I will respond to one line of objection to my interpretation and will conclude by considering how Plato's characterization of Protagoras as a hedonist is meant to undermine Protagoras' status as a teacher of virtue.

It should be noted right away that Plato's portrayal of Protagoras as hedonist, if my view is correct, operates primarily at the level of insinuation and dramatic nuance. That is to say, I do not think anything said in the dialogue logically entails that Protagoras is, or that Plato believes he is, committed to hedonism. Nonetheless, a number of strong signs in the Protagoras - which I will supplement with material from other dialogues - support the reading I will defend, and a plausible and compelling case can be made in its favor.

\section{PRotagoras the SOPHIST}

When an excited Hippocrates announces to Socrates that Protagoras has arrived in Athens, Socrates replies, "Day before yesterday. Did you just now find out?"3 His response suggests that he is unimpressed: he already knew Protagoras was in town but evidently felt no inclination to meet him. When Hippocrates expresses his eagerness to visit Protagoras and gain some of his "wisdom," however, Socrates' apparent indifference turns to solicitude. He

function that does not require that any of the participants in the dialogue be committed to it. Finally, Wolz $(1967,217)$ and Woolf $(2002,248$ n. 44) both deny that the issue of to whom the dialogue's hedonism should be attributed is important for understanding the dialogue. I take my own interpretation to be especially indebted to, and aligned on many key points with, the accounts of Duncan, Dyson, Ebert, Grube, McCoy, Sesonske, Sullivan, and A. E. Taylor.

3. Translations of Greek, with modifications, are from Cooper (1997). 
wants to know precisely what kind of "wisdom" Hippocrates expects to gain from the reputed educator, and when Hippocrates is unable to provide a satisfactory answer, Socrates issues a note of caution (313a1-b2):

\footnotetext{
Do you see what kind of danger you are about to put your soul in? If you had to entrust your

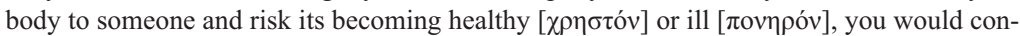
sider carefully whether you should entrust it or not, and you would confer with your family and friends for days on end. But when it comes to something you value more than your body, namely your soul, and when everything concerning whether you fare well or badly in your

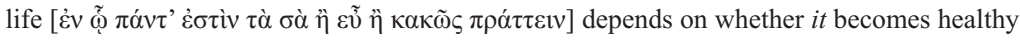

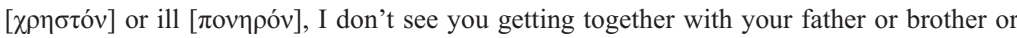
a single one of your friends to consider whether or not to entrust your soul to this recently arrived stranger.
}

Socrates' unease is especially acute given that Protagoras is a sophist, which Socrates takes to be "a kind of merchant" or "peddler." Socrates' worry is that these itinerant "merchants" may market their teachings indiscriminately, without knowing whether they are good or bad for the soul, just as food merchants recommend all of their products without knowing whether they will be good or bad for the body. Only a "physician of the soul" would know whether a given set of teachings is good or bad for the student, just as only a doctor would know which foods and drinks are good or bad for the body (313c-314b).

It is this set of concerns that ostensibly sets the agenda for their subsequent conversation with Protagoras. Socrates wants to find out whether Hippocrates will be benefited or harmed - whether he will fare well or badly in life - by taking on the famous sophist as an instructor. When they finally meet Protagoras and make their query to him, Protagoras promises to be able to make his students "better" people, to teach them sound deliberation ( $\varepsilon \dot{\beta} \beta o v \lambda i$ í $)$, to make them good citizens, and, finally, to teach them virtue and make them noble and good. Despite the inherent appeal of the goods Protagoras advertises, however, Socrates' earlier warning leaves an important question lingering over their whole discussion: Is Protagoras merely peddling his wares? ${ }^{4}$

I believe the dialogue as a whole is largely intended to address this question in the affirmative - to show that Protagoras is a salesman, that he does not know what is good or bad for the soul, and that he is not fit to make his students virtuous and good. As I aim to show in what follows, it does so in part by depicting Protagoras as having latent or implicit ties to hedonism.

\section{SOPHISTRY AND THE MANY}

The first reason for thinking that Plato views Protagoras as an advocate for hedonistic views in the dialogue concerns his profession. In the Gorgias Socrates describes rhetoric as a "knack" for producing "a certain gratification and pleasure" (462c3-7). It is a form of flattery, he says, which "takes no thought at all of what is best," but rather deceives its audience "with the lure of what's most pleasant at the moment" (465d1-3). It has its effect, Gorgias himself testifies,

4. Duncan $(1978,216)$ also emphasizes that "the guiding question of the dialogue is whether Protagoras will really be able to deliver the goods he publicly offers, to Hippocrates or anyone else." 
on "judges in a law court, councilors in a council meeting, and assemblymen in an assembly or in any other political gathering that might take place" (452e14). Here we find at least one way in which Plato takes Protagoras to be a champion of hedonism: by his profession as a sophist. Throughout his dialogues Plato characterizes sophistry and rhetoric as practices that aim at pleasing their audiences. ${ }^{5}$ In particular, the success of these practices depends on their capacities to provide pleasure, and to teach others how to provide pleasure, to the Many. If that is the case, then the obvious implication is that Protagoras, given his profession, must adapt his teachings and speeches to the hedonistic views and inclinations of his audiences. His success as a sophist and orator requires that what he is "selling" be attractive to a diverse variety of people - both to his potential clients themselves and to the throngs over whom they hope to hold sway - and that means gratifying the pleasure-centric appetites and attitudes that control most people's lives. Protagoras is, in other words, professionally bound to act as an advocate of sorts for hedonism: he must promote the kinds of skills and views that are consistent with, and appealing in light of, the hedonistic values to which the Many are (implicitly or otherwise) committed.

There is a further point, however, which a notable passage from the Republic helps bring to light. During his "defense" of philosophy in Book 6, Socrates comments (493a-d):

Not one of those paid private teachers, whom the people call sophists and consider to be their rivals in craft, teaches anything other than the convictions that the majority express when they are gathered together. Instead, these are precisely what the sophists call wisdom. It's as if someone were learning the moods and appetites of a huge, strong beast that he's rearing ... Having learned all this through tending the beast over a period of time, he calls this knack wisdom, gather his information together as if it were a craft, and starts to teach it. In truth, he knows nothing about which of these convictions is admirable or shameful, good or bad, just or unjust, but he applies all these names in accordance with how the beast reacts - calling what it enjoys good and what angers it bad. He has no other accounts to give of these terms. And he calls what he is compelled to do just and admirable, for he hasn't seen and cannot show anyone else how much compulsion and goodness truly differ. Don't you think, by god, that someone like that is a strange educator? ... And does this person seem any different from the one who believes that it is wisdom to understand the moods and pleasures of the multifarious [ pantodapôn] Many when they are gathered together?

This passage illustrates not only that sophists pander to the pleasures of the Many, but also that the sophists' own conceptions of what is valuable may be informed by those very pleasures. According to Socrates, sophists have nothing more to say about what it means for something to be good or bad other than that it pleases or displeases the crowd. The implication is that the reason they have "no other account" to offer of these terms is that they accept the views of the many to whom they pander. At the very least, Socrates makes it clear that sophists are ignorant of what is truly valuable: they "know nothing" about what is admirable, just, or good, and have never "seen the difference" between

5. In the Theaetetus, for example, Socrates compares the life of the philosopher with that of the individual who spends his time "in law-courts and such places." The latter is like a slave, he says, who becomes "skilled in flattering the master and working his way into favor" (172c-3). 
goodness and necessity. The fact that they call the convictions of the Many "wisdom," however, suggests furthermore that in their ignorance of what is truly good, they actually come to believe that what pleases the Many really is good. The consequence for the current discussion is clear: if Protagoras' profession renders him incapable of providing, or even acknowledging the existence of, any account of the good other than what the pleasures of the Many suggest, then his own view of goodness will turn out, like that of the disparate crowd, to be one that inclines toward hedonism. ${ }^{6}$

An important passage in the Protagoras may hint at just such an impoverishment in the sophist's views. At $334 \mathrm{a}-\mathrm{c}$, during a discussion about the relationship between temperance and justice, ${ }^{7}$ Protagoras delivers a short speech on the nature of goodness. After Protagoras grants the point that some things are, in fact, good ( $\dot{\alpha} \gamma \alpha \theta \dot{\alpha})$, Socrates next asks him whether "good things" refers to what is advantageous $(\dot{\omega} \varphi \varepsilon ́ \lambda \iota \mu \alpha)$ to people. "Good God, yes!” Protagoras answers, "And even if they are not advantageous to people, I can still call them good." Perceiving Protagoras' exasperation, Socrates carefully asks whether Protagoras means things that are advantageous to no human being, or things that are of no advantage at all. "Do you call things like that good?" he asks. Protagoras then responds (334a3-c6):

Of course not. But I know of many things that are disadvantageous [ $\dot{\alpha} v \omega \varphi \varepsilon \lambda \tilde{\eta}]$ to humans, foods and drinks and drugs and many other things, and some that are advantageous; some that are neither to humans but one or the other to horses; some that are advantageous only to cattle; some only to dogs; some that are advantageous to none of these but are so to trees;

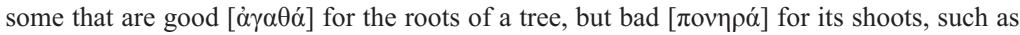
manure, which is a good spread on the roots of any plant but absolutely ruinous if applied to the new stems and branches. Or take olive oil, which is extremely bad for all plants and is the worst enemy of the hair of all animals except humans, for whose hair it is beneficial, as it is for the rest of their bodies. But the good is such a complex [ $\pi$ oเкínov] and manifold $[\pi \alpha v \tau o \delta \alpha \pi$ ó $]$ thing that, in the case of oil, it is good for the external parts of the human body but very bad for the internal parts, which is why doctors universally forbid their sick patients to use oil in their diets except for the least bit, just enough to dispel a prepared meal's unappetizing aroma.

The speech is met with approval and applause by the crowd in attendance, and the particular line of argument Socrates had been pursuing is never revived.

In the broader context of the dialogue, Protagoras' speech is noteworthy for at least two reasons. First, it represents the only point in the text prior to the final discussion of hedonism in which the nature of the good is directly addressed. Given the importance of the later discussion, 334a-c may be intended to anticipate or prepare the way for it in some way. ${ }^{8}$ Second, Socrates'

6. Ebert $(2003,19)$ claims that if we focus on the fact that the dialogue stages a conference of leading sophists, Socrates' attention to the views of the Many in the Protagoras is inexplicable, given that the sophists disdain the Many. What the above arguments show, however, is that whether they like it or not, the sophists have inextricable ties to the Many's beliefs.

7. The broader context is a disagreement between Protagoras and Socrates concerning the unity of the virtues, in which Socrates protests Protagoras' suggestion that the various virtues are completely different and dissimilar from one another.

8. Goldberg $(1983,127-28)$ also notes the significance of 334a-c in connection with the final argument: "Given the course of the overall argument, it is no accident that the final breach in this part arises over the nature 
cautionary conversation with Hippocrates had called into question whether Protagoras truly knows what is good or bad for his clients' souls. Here Protagoras offers a glimpse of how he understands goodness, which bears on precisely that question.

What I would like to suggest here is that that the dramatic and dialectical function of the speech is to raise further doubts about Protagoras' understanding of the good, and thereby to make room for his role as a spokesperson for the Many's hedonism in the final argument. Two features of Protagoras' speech are relevant in this regard. To begin with, the sorts of goods Protagoras considers are exclusively bodily in nature: they concern only "food and drinks and drugs" and whether those things will have a "beneficial" or "ruinous" effect on the physical health and bodily condition of an organism. While Protagoras does not deny that there are other kinds of goods, of course, his emphasis on the bodily as opposed to the psychological - in contrast to the importance Plato places on the latter - may be intended to bring to the reader's mind Socrates' earlier warning to Hippocrates, and to raise doubts about how much Protagoras really knows about genuine goods of the soul. ${ }^{9}$

Second, the two terms Protagoras uses to describe the good in his speechpoikilon and pantodapon, or "complex" and "manifold" - are significant: Plato uses the terms throughout the dialogues in ways that suggests he associates them with problematic diversity and (at least perceived) lack of unity. Significantly, Socrates sometimes criticizes his interlocutors for characterizing important moral objects of inquiry using these two terms. When Socrates asks the young Theaetetus to offer a definition of knowledge, for instance, and the latter responds with a list of several specific branches of knowledge, Socrates replies that Theaetetus has generously offered something "complex" ( poikila) instead of something simple: "Having been asked for one answer, you have given many" (Tht. 146d4-5). Similarly, when Meno claims to know what virtue is, but then proceeds to describe several different types of virtue that vary from group to group, Socrates responds that he has offered a "swarm" of virtues instead of just one. Suppose, Socrates says, that Meno had offered an account of the nature of bees by stating that they are "many and of all kinds [pantodapas]," and that Socrates were to ask him whether they are "many and of all kinds [pantodapas] and different from one another insofar as they are bees" (Meno 72a9-b5). Meno sees that they would not differ in that respect, and Socrates concludes, "The same is true in the case of the virtues. Even if they are many and of all sorts [pantodapoi], all of them have one and the same

of the good and is applauded by the many. Before the logos can make further progress, at least a provisional definition of the nature of the good must be agreed to by the audience and hence by Protagoras."

9. It may also be significant that when Socrates wants to elicit hedonism from Protagoras later in the text, he returns to many of the same bodily goods and evils that the sophist cites at $334 \mathrm{a}-\mathrm{c}$. The questions Socrates asks during that later discussion reveal that - at least on the view of the Many for whom Protagoras is speaking - the goodness and badness of all of the "benefits" and "harms" mentioned in Protagoras' earlier speech are reducible to pleasure and pain. What it means for foods and drinks to be "ruinous" for the body is that they promote disease, and "these things are bad on account of nothing other than the fact that they result in pain and deprive us of other pleasure" (353c-354a). Likewise, the treatments provided by doctors, such as surgery, medicine, and diet, are good because they promote health and good condition of the body, which in turn "are good because they result in pleasure and in the relief and avoidance of pain" (354a-b). 
form that makes them virtues" (72c6-d1). In the Theaetetus and Meno Socrates urges his interlocutors to look past the apparent diversity of different types or instances of knowledge and virtue in order to see what they have in common. In both cases, their ultimate inability to accomplish that task is taken as a sign of their ignorance. Protagoras' use of poikilon and pantodapon, therefore, shows at least that his characterization of goodness is not one that Socrates or Plato would find satisfying taken by itself. Of course, because Socrates does not immediately press the sophist, as he does with Theaetetus and Meno, to provide a unified account of the good, it is left open at this point how Protagoras would respond to further questioning on the matter. However, the fact that Protagoras uses terms that prominently appear in inadequate characterizations of moral concepts in other dialogues at least draws the reader's attention - as did the earlier warning to Hippocrates - to the possibility that the sophist might have "no other account" to offer of the good, and hence might not know what is truly beneficial for the souls of his clients. ${ }^{10}$

The significance of poikilon and pantodapon may be amplified by a further point, moreover: as a number of commentators have observed, the content of $334 \mathrm{a}-\mathrm{c}$ bears a strong resemblance to the Dissoi Logoi, which also provides an extended list of things that are good for one individual or in one context, but bad for another individual or in another context. ${ }^{11}$ Although the language and message of the two texts are strikingly similar, however, the words poikilon

10. Some previous commentators - including A. E. Taylor 1927, 251; Adam and Adam 1957, Versenyi 1962, 179; Vlastos 1956, xvi-have defended a much stronger conclusion about 334a-c: that it is a statement of Protagorean relativism or subjectivism of the sort associated with the Man-Measure doctrine. A. E. Taylor, for example, calls the passage "a direct and simple application of Protagoras' own principle of 'man the measure' to ethics." My own interpretation is much more conservative, but I am sympathetic (particularly in light of considerations about the Man-Measure doctrine that I will raise in the next section) at least to the idea that 334a-c might be intended to bring the sophist's famous doctrine to mind. Some commentators have vigorously objected to such ways of reading 334a-c, however, on two main grounds: (1) Protagoras' speech appears to invoke an objective standard for evaluating goodness - the beneficial - that importantly does not seem to be relative to the perception or judgment of the thing benefitted. Thus C. C. W. Taylor (1976, 133-34), for example, calls it "sheer confusion" to suppose that the content of 334a-c either entails or follows from Protagorean relativism: "Protagoras' speech does not imply that if anyone believes something is good, then it is good (for him)." Cf. Kerferd 1949, 24; McCoy 1998, 31. (2) The types of facts Protagoras cites in his speech are not evidently ones that Plato would or should protest. Moser and Kustas $(1966,114)$ comment, "One is tempted to the facetious remark that if Protagoras' thought here is described as relativism, the absolutist would have to maintain that the same medicines are good for everybody or the same diet for all animals!" In response to (1), it should be conceded that the letter of $334 \mathrm{a}-\mathrm{c}$, taken all by itself, is consistent with denying subjectivism about the good. However, nothing in the speech itself indicates what Protagoras takes "beneficial" and "harmful" to mean, and we cannot simply assume that, if pressed, he would give them an objectivist treatment. Indeed, when Socrates actually turns to tackle the issue of what it means for something to be good or bad at $353 \mathrm{c}-355 \mathrm{e}$, it is from Protagoras' own lips (albeit ostensibly as a spokesperson for the Many) that beneficial and harmful states turn out to be reducible to subjective states of pleasure and pain. Even if the straightforward content of Protagoras' speech on goodness does not entail subjectivism, therefore, it may nonetheless be intended to bring such a view to the reader's mind and to raise the possibility of its latency within the sophist's remarks. In response to objection (2), it is true Plato does not object to the facts Protagoras cites. Indeed, the idea that if something is good in any context, it must be good in every context, is precisely the sort of insidious casuistry against which Plato is reacting in dialogues such as the Euthydemus. Certainly Plato was aware that what is good for one person or thing is not necessarily good for another person or thing. The fact that Plato shares that premise with the Protagoras of 334a-c does not settle the question whether he means to portray the sophist as an advocate of relativism or some other related doctrine, however. For the crucial difference between Plato and Protagoras concerns how they explain their shared premise. Plato thinks that what is good varies for different people and things because people and things are diverse and variable; Protagoras thinks the good varies because it is itself diverse and variable.

11. Graham $(2010,722)$ and Versenyi $(1962,181)$, e.g., note this connection. 
and pantodapon never occur in the Dissoi Logoi. They are, in other words, Plato's own addition to a stock sophistic argument.

Second, it is perhaps significant that Plato commonly uses the two terms to characterize both the democratic Many themselves and the appetites and pleasures by which they are ruled. This characterization of democracy and its citizens is most striking in Book 8 of the Republic, where we find by far the highest concentration of the terms poikilon and pantodapon in the whole corpus. There Socrates describes democracy as a "pleasant" constitution that is full of variety (poikilon, 561e4), and he comments (557c1-9):

I suppose that it's most of all under this constitution that one finds people of every sort [pantodapoi] ... It looks as though this is the most beautiful of the constitutions, for like a colorful [poikilon] coat that is embroidered [pepoikilmenon] with every kind of hue, this city, embroidered [ pepoikilmenê] with every kind of disposition, would also appear to be the most beautiful. And Many [polloi] would probably judge it to be so, as women and children do when they see colorful things [poikila].

Democratic individuals and citizens, moreover, resemble the democratic city itself. Those who live in democracy, because they are free to live however they want, end up living in whatever way "pleases" them (561e). Democatic individuals are controlled by their unnecessary appetites, and the democratic man is "complex [pantodapon], full of a multitude of dispositions, beautiful, and full of variety [poikilon]," who comes into existence as a result of associating with those who provide diverse (poikilas) pleasures of every sort ( pantodapas). Also in the Republic, Socrates claims that it is difficult to provide a single name for the appetitive part of the soul because of its polymorphous na-

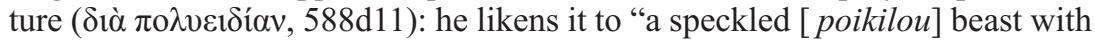
a ring of many heads that it can grow and change at will" (588c7-10), and he calls it "the multiform [ pantodapon] beast" within us (588e5). ${ }^{12}$ Importantly, Plato's use of poikilon and pantodapon in such contexts far exceeds typical Greek usage. By way of comparison, whereas poikil- and pantodap-words are used to describe the Many, appetite, or pleasure fifteen times in Republic 8 and 9 alone, they appear only three times in the Nicomachean Ethics, and never in

12. For further examples of Plato's strong association of poikilon and pantodapon with pleasure, appetitive impulses, and the Many, see also Lysis 222b2; Grg. 489c5, 490b3, 522a3; Phd. 66c3; Hp. mai. 282d1; Symp. 182b1; Resp. 373a4, 404d2, 431b9, 559d9, 568d6, 579b4, 616a5; Tht. 168c2; Ti. 87a5; Laws 645a4, 665c6, 704d7, 782a7, 797b1, 788b2, 831d9, 949e8. Also note Phil. 12c4-9, where Socrates declares, "As for pleasure, I know that it is full of variety ( poikilon)... If one just goes by the name it is one single thing, but in fact it comes in many forms that are in some way even quite unlike each other." Plato also frequently applies the two terms to sophistry and rhetoric (Ion 541e7; Hp. mi. 363c1, 368d2; Symp. 193e7, 198b3; Phdr. 236b7, 277c2; Soph. 223c2, $225 \mathrm{c} 5 ; 226 \mathrm{a} 6-7,234 \mathrm{~b} 4)$, as well as to popular poetry (Resp. 397c5, 398a1, 399e9, 399e10, 404e3, 605a2; and at Laws 665d6, 665 $6,812 \mathrm{~d}-\mathrm{e}$ ). As a general rule, in fact, Plato uses poikilon, pantodapon, and their cognates primarily to describe (typically with critical overtones) psychologies, practices, and people that he associates with appetitive desire: pleasure (the object of appetitive desire); the appetitive part of the soul; democracy and the democratic Many (who are associated with "unnecessary" pleasures; and sophistic and poetic practices that appeal to pleasure. There are exceptions to this rule, particularly in mythical or natural philosophical contexts in which Plato is describing the colorful and variable perceptible world itself (e.g., Phd. 110b7; Tht. 156c1, Resp. $616 \mathrm{e} 9$; and Ti. 50d5, 57d5, 61c4, and 67c5), or, in the case of poikilon, when he is using the term in its literal sense to refer to embroidery and weaving (Resp. 373a7 and 401a2). In the great preponderance of cases, however, poikilon and pantodapon have evaluative or moral connotations in Plato and describe things toward which his attitude is one of disapproval-in particular, appetitive desire and the various psychological and political phenomena Plato associates with it. 
Aristotle's Politics or De anima. This suggests that the appearance of poikilon and pantodapon in Protagoras' speech - and as a description of the good, no less - may signal insinuations on Plato's part that Protagoras' conception of goodness is somehow or other impoverished, and that it informed by, or at least designed to appeal to, the convictions of the diverse and appetitive crowd on whom he exercises his persuasive powers.

\section{THE MAN-MEASURE DOCTRINE}

A further case for thinking that Plato takes Protagoras to be implicitly inclined toward hedonism can be constructed by examining Protagoras' Man-Measure doctrine as Plato understands it. According to Protagoras' most famous maxim, "Man is the measure of all things: of the things which are, that they are, and of the things which are not, that they are not" (Tht. 152a2-4). In the Theaetetus, with the help of his interlocutors and an appearance by the "resurrected" Protagoras himself, Socrates examines the meaning and philosophical implications of this maxim and presents an account of the Protagorean doctrine associated it. While many of the details of that discussion are a matter of much dispute, two points are relatively clear. ${ }^{13}$ First, Plato takes the Protagorean view prominently to include or entail a thesis about sense-perception: that perceptual experiences are infallible. Indeed, the occasion for discussing the Man-Measure doctrine is prompted precisely by Theaetetus' proposal that knowledge is the same as perception, which Socrates suggests is exactly "what Protagoras used to maintain" (152a1). According to the Protagorean maxim, Socrates says, if something appears a certain way to a person, then it is in fact that way for him. A wind that appears cold to one man but warm to the other, for instance, really is cold for the one and warm for the other (152b). Appearances, moreover, are closely connected to, and in some cases even identical with, instances of sense-perception. Socrates points out that "it appears" often just means "he perceives it," and he concludes that according to the view Theaetetus shares with Protagoras, "The appearing of things is the same as perception, in the case of hot and everything of that sort. So it results, evidently, that things are for the individual such as he perceives them . . Perception, then, is always of what is and is unerring" (152c1-6; cf. 160a9-c7). The second point, which is closely related to the first, is that Plato takes Protagoras' Man-Measure doctrine to undermine the distinction between how things appear and how they actually are. If things always are however they are perceived by and appear for people, then there is no room for false appearances or judgments. As Plato has Protagoras himself put it, "It is impossible to judge what is not, or to judge anything

13. My interpretation does not require me to take a position on several of the most pressing interpretive issues, including: (1) precisely how Plato understands and presents the relationship between Protagoreanism and the Heraclitean doctrine of flux in the dialogue; (2) the extent to which the presentation of the Man-Measure doctrine-including the emphasis on its connection to sense-perception-and the various defenses of it that are offered in the text are derived from genuine Protagorean material or from Plato's own understanding of the doctrine and its significance; (3) whether Plato's depiction of the Man-Measure doctrine is best construed as relativism or infallibilism, and what particular sort of each; and (4) what the nature and logical structure of Socrates' refutation of the Man-Measure doctrine is. Many of these controversies and others are laid out and discussed at length in Burnyeat 1990. 
other than what one is immediately experiencing; and what one is immediately experiencing is always true" (167a7-8; cf. 161e-162a).

Drawing on this Platonic characterization of Protagoreanism, I would like to suggest that on Plato's view, the Man-Measure doctrine leads naturally (even if not necessarily or as a matter of logical entailment) to hedonism. ${ }^{14}$ From a Platonic perspective, the hedonistic identification of the good with pleasure is a predictable psychological consequence of the view that perceptual experiences and the judgments derived from them are always true. For pleasure is an especially salient and compelling sensory experience, and pleasant objects and pleasure itself have an apparent value to those affected by them. In the absence of any distinction between appearance and reality, then, the belief that all, and perhaps even only, pleasure is good seems almost inevitable. Plato, at any rate, certainly seems to think that the line between experiencing something as pleasurable and judging it to be good is perilously thin, and that those who unreflectingly accept the reports of their senses will tend in a hedonistic direction. In the Phaedo, for example, Socrates warns of what he calls the "greatest and most extreme evil" caused by pleasures and pains (83c5-d7):

That the soul of every man, when it feels violent pleasure or pain in connection with some object, is forced to believe at the same time that what causes such feelings must be very clear and very true, which it is not ... Every pleasure and pain provides, as it were, another nail to rivet the soul to the body and to weld them together. It makes the soul corporeal, so that it believes the truth is what the body says it is.

By their very nature, experiences of pleasure and pain have the power to incline us toward the view, not only that pleasures are good and pains bad, but that there is nothing more to goodness or badness than pleasure and pain: they "bewitch" the soul, Socrates says, "to the point at which nothing seems to exist for it but the physical, which one can touch and see or eat and drink or make use of for sexual enjoyment." The value judgments that lie the shortest distance from our perceptual experiences, in other words, are the sort that foster

14. Some commentators express skepticism about drawing on Plato's characterization of the Man-Measure doctrine in the Theaetetus for the purposes of reading the earlier dialogue. Moser and Kustas (1966, 113 n. 6), e.g., write, "The Protagoras should be explained out of itself. The presence of the doctrine of relativism in the Theaetetus cannot serve as a touchstone for interpreting the earlier dialogue." See also Kerferd 1953, 45; Schiller 1908, 523. I do not share their methodological worry, however, for a number of reasons: (1) The Man-Measure doctrine was not an obscure component of Protagoras' teachings; rather, it was, even in Plato's own time, one of his most well-known and celebrated views. In the Theaetetus Socrates is able to assume that his young interlocutor is familiar with the Man-Measure doctrine, and Theaetetus confirms that he has read it "many times." Given the fame Protagoras' maxim had achieved, therefore, Plato the author could be sure that his readers would be familiar with it and that it would color their understanding of the text. We might compare the way that Plato could expect his readers' knowledge of Meno's ill-fated career to color their reading of the Meno. (2) There is no reason to suspect that the characterization of the Man-Measure doctrine sketched in the Theaetetus - particularly the two main points of that characterization important to my account - represents an exception to Plato's general attitude toward, or understanding of, Protagoras' view. (Note als the characterizations of Protagoreanism found in Cra. 385e-386a and Euthyd. 286b-c, which suggest Plato's awareness of, and stability in his interpretation of, Protagoreanism at various stages throughout his career.) (3) There are a number of shared concerns and thematic similarities between the two dialogues that suggest a closer connection between them than is sometimes supposed. These include, among others: (a) the question whether Protagoras is qualified as an educator (Tht. 161d-162a, 167d); (b) the characterization of education as a process of making the soul's condition $\chi \rho \eta \sigma \tau o ́ v$

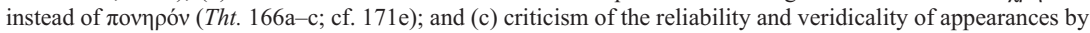
appealing to the future (Tht. 178b-179c). I discuss (c) at greater length in section 6. See also n. 30. 
hedonism. ${ }^{15}$ A doctrine that affirms the infallibility of perception, therefore, will be one that justifies, and tends to lead toward, living and thinking hedonistically. ${ }^{16}$ Even if Plato does not think the Man-Measure doctrine logically entails hedonism, then, he at least takes its central commitments to be ones that lead naturally to it. If that is the case, then it is reasonable to conclude that the conspicuous appearance of hedonism in a dialogue that prominently features Protagoras himself is partly intended to explore some of those latent connections. ${ }^{17}$

\section{Protagoras' Character AND LifEStyle}

Let us turn now to Protagoras' character. Two features of Plato's portrayal of the sophist's personality and lifestyle suggest a man with hedonistic tendencies. The first is that, at two key points throughout the dialogue, Protagoras expresses his eagerness to do what will be pleasant. When Socrates asks him whether he would like to speak in private or in front of the crowd, Protagoras answers, "It would give me the greatest pleasure by far to deliver my lecture in the presence of everyone in the house" (317c4-5). Similarly, when the group decides that Protagoras should himself choose whether to present his Great Speech in the form of a story or an argument, he decides, "I think it would be more pleasant if I told you a story" (320c6-7). The contrast may be significant: instead of presenting a rational argument $(\log o s)$, presumably the more philosophical choice, the sophist decides to do what he considers more pleasing.

If this first aspect of Plato's portrayal of the sophist is relatively subtle and inconclusive, the second is more substantial. Plato draws a great deal of attention in the dialogue to the fact that the sophist charges extravagant fees for his reputed teachings. Indeed, the sophist's attraction to money seems to be one of the defining features of his character. One of the very first comments made

15. The idea, I take it, is that if an agent believes nothing is "true" or "real" except what the body experiences, then the agent's reasoning about value will look no further than what appears valuable as a result of sense perception, and hence will come to see goodness only in pleasure. It does not matter for my purposes whether the Phaedo (and with it, perhaps, the Republic) takes bodily or perceptual experiences themselves to be genuine "beliefs" in the way that the Theaetetus denies (at 184b-187a). The important point is simply that, throughout his career, Plato thought that painful and pleasurable experiences, particularly intense ones, incline us in a compelling way, and often immediately, toward judging that pain is bad and pleasure is good. The ways in which our bodily nature, and in particular its experiences of pleasure and pain, can lead toward errors in evaluative judgment is explored throughout the Phaedo (esp. 64d-65c, 66b-e, 79c, 82e-83c) as well as in the Republic-for example, at $518 \mathrm{~d}-519 \mathrm{~b}$, where Socrates likens pleasures and pains to "leaden weights" that drag the soul's vision downward. It is also implied by Grg. 465c-e, where Socrates suggests that if the body were left to govern itself, it would

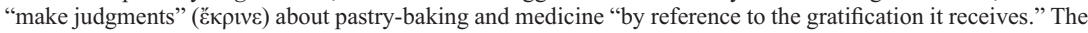
general connection between our bodily nature and appetitive desire for pleasure is suggested by Resp. 439c-d: the desires of the appetitive part, which is called a "companion of certain indulgences and pleasures," are taken to be derived from (bodily) "feelings and diseases" (cf. Ti. 70d7-8).

16. Other commentators who have noted and discussed connections between the Man-Measure Doctrine and hedonism include Dimas 2008, 256; Duncan 1978, 222-24; Grube 1933; McCoy 1998, 34-36. Grube comments, "Indeed, what other criterion but pleasure could be given by the man who taught that individual sensations and feelings are the only reality?" (206).

17. Other commentators who identify traces of the Man-Measure Doctrine in the Protagoras often focus on relativistic or subjectivist implications of either 334a-c (see discussion in n. 10 above) or the Great Speech. The latter group includes A. E. Taylor (1927, 245-47), Vlastos (1956, xii-ix), and McCoy (1998), who offers an especially in-depth and insightful analysis. Critics of these lines of interpretation include Kerferd (1953, 4-5) and Moser and Kustas (1966, 111-13). 
about Protagoras is Hippocrates' complaint that the sophist has a "monopoly on wisdom" and refuses to give it to him, to which Socrates responds, "But look, if you meet his price he'll make you wise too" (310d6-7). The theme of the subsequent discussion then becomes whether Protagoras is worth his fees, which, as we have seen, culminates in Socrates' characterization of sophists like Protagoras as "merchants" or "peddlers."18 Protagoras himself confirms his interest in profit. In his Great Speech he equates "the most capable" with "the richest" (326c), and he concludes his speech by declaring, "I consider myself . . . uniquely qualified to assist others in becoming noble and good, and worth the fee that I charge and even more" (328b1-4). Finally, Socrates calls Protagoras "the first ever to have deemed it appropriate to charge a fee" for teaching virtue (349a3-4).

The portrayal of Protagoras as a moneymaker is significant in light of Plato's understanding of the pursuit of wealth as a characteristically pleasure-oriented expression of desire. In the Republic Plato identifies "love of wealth" or "love of profit" as one of the most conspicuous manifestations of appetitive desire. The appetitive part of the soul is "by nature most insatiable for wealth," and it is rightly called "money-loving" because its excessive desires for the pleasures of food, drink, and sex "are most easily satisfied by means of money" (442a, $580 \mathrm{e}-581 \mathrm{a})$. Love of wealth is also the distinctive feature of the oligarchic individual, who is ruled by the appetitive part of his soul. The oligarchic individual is a "money-lover" whose rational thoughts and ambition are focused on gaining wealth, and he lives by satisfying his necessary pleasures and appetites, which "are generally in control of" his unnecessary desires (553b-554a). The fact that Plato emphasizes Protagoras' desire to profit from his profession, then, suggests that he takes the sophist to be controlled by his appetites, and to place supreme value on pleasure and the money that facilitates its obtainment. Protagoras, in other words, turns out to be a sort of hedonist, one who is not unlike the oligarchic man of the Republic. ${ }^{19}$

\section{5. "ReveAling” Protagoras}

Some commentators have objected to ad hominem readings of the dialogue on the grounds that both Protagoras and the Many seem disposed to resist hedonism when Socrates first introduces it. Protagoras is comfortable granting

18. Throughout that brief conversation the characters refer to Protoagoras' fees no fewer than ten times (see esp. 311c-e, 313b, 314b). Cf. mention of Protagoras' fees at Tht. 161d-e, 167c-d, 178e-179a; Hp. mai. 282c-d.

19. It may also be significant that love of money is associated, both within Plato and in other sources, with akrasia - precisely the phenomenon that Socrates addresses in the final section of the dialogue. In Republic 8 it is the oligarchic individual (in contrast to the philosophical and timocratic individuals) who first becomes "in some sense two" and subject to internal conflict. The fact that his better desires master his worse ones only "for the most part" strong implies that they do not always succeed (554d-e). Along similar lines, in the Laws Plato refers to crimes that are due to "weakness [ๆ̆ $\tau \alpha \varsigma]$ in the face of pleasures, appetites, and envies," and he explains that the greatest of these causes is appetite, which "is most usually for money, the object of the Many's strongest and most frequent longing: because of wickedness due to nature and lack of education, money has the power to produce in them a million cravings that are impossible to satisfy - all centering on the endless acquisition of wealth" (869e-870a). Outside of Plato, we find from the Anonymous Iamblichi the claim, "Every man must have as much self-control as possible. And someone would achieve this if he were indifferent to money, by which everyone is corrupted ... The Many are weak-willed; and this is why they behave that way: . . they love money because of the things that frighten them" (98.17-99.5 in Graham 2010). 
that living well is incompatible with a life of pain and distress, and that those who have lived their lives pleasantly have thereby lived well. Concerning the explicit question whether to live pleasantly is good, however, Protagoras adds the caveat that it is good only if the pleasure is taken in honorable things. Socrates responds, "What, Protagoras? Surely you don't, like the Many, call some pleasant things bad and some painful ones good?" (351c2-3). Although Protagoras believes it is "safer" for him to answer as the Many do on this point, Socrates pushes him by asking whether all pleasurable things are good just insofar as they are pleasurable - whether, that is, pleasure itself is a good. Protagoras replies, "Just as you always say, Socrates, let us inquire into this matter, and if your claim seems reasonable and it is established that pleasure and the good appear to be the same, then we will come to agreement" (351e3-6). Critics of ad hominem readings argue that Protagoras' and the Many's reluctance to accept hedonism and its corollaries shows that neither of them is really hedonistic; rather, it is Socrates who must convince them to identify the good with pleasure, against their own objections. ${ }^{20}$

Several considerations tell against this line of criticism. The first is simply that Plato can take Protagoras and the Many to be hedonistic and (at least implicitly) committed to hedonism without also thinking that their hedonistic views are fully worked out and consistent. A passage from the Republic is illuminating. While investigating the nature of the good, Socrates says, "You surely know that the Many believe the good is pleasure, while the more sophisticated believe that it is knowledge." Then, after explaining how the latter group runs into difficulties, he asks (505b5-c11):

"What about those who define the good as pleasure? Are they any less full of confusion than the others? Aren't even they forced to admit that there are bad pleasures? . . . So, I think, they have to agree that the same things are both good and bad. Isn't that true?"

What these comments suggest is that Plato takes the many to be committed both to hedonism and (despite its being in tension with hedonism) to the view that some pleasures are good or honorable and others bad or dishonorable. ${ }^{21}$ At any rate, it is clear that Plato did not find it implausible for these two commitments to sit (uncomfortably, in his mind) alongside one another. ${ }^{22}$ If that is the case, then the fact that Protagoras and the Many have commitments that

20. See Dodds 1959, 21 n. 3; Dyson 1976, 43; Ferrari 1990, 132-34 n. 29; Grote 1888, 314; Hackforth 1928, 41; Irwin 1977, 309 n. 13; Nussbaum 1986, 111. Ferrari, for example, writes, "The fact that Socrates must argue his interlocutors into hedonism is meant to suggest to us that hedonism is not their belief - not even their underlying belief" (133 n. 29); and Grote comments that Protagoras is "compelled to accept the conclusion against his own will" (314).

21. I take the Socrates of the Gorgias to be exploiting more or less the same pair of inconsistent beliefs in his exchange with Callicles. In the Gorgias, however, the inconsistency is resolved in the other direction: the Many of the Protagoras call some pleasant things bad despite their hedonism, and Socrates leads them toward consistency by making them abandon the former view; conversely, Callicles insists on hedonism, and Socrates tries to undermine that commitment by showing Callicles that he views some pleasures as shameful.

22. Klosko $(1980,312)$ provides a similar explanation, as does Santas $(1966,8$ n. 7), who writes, "As for the question why did Socrates use hedonistic premises in his argument, I see no mystery at all here, for the argument is in fact a perfect example of Socrates' favorite mode of argument; it attempts to show that one belief of the many ... is incompatible with another belief of theirs, the belief in hedonism." 
are in tension with hedonism does not settle the question whether hedonism is one of their views.

The second consideration concerns Protagoras himself. What the course of his conversation with Socrates makes clear is that the sophist is far from forthright in stating his beliefs. Socrates must repeatedly urge Protagoras to express his own ideas and allow his own mind to be tested. Socrates chides him early in their conversation, "Don't do that to me! It's not this 'if you want' or 'if you agree' business I want to test. It's you and me I want to put on the line" (331c4-

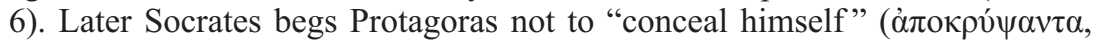
338a6) behind rhetoric, and after Protagoras diverts their conversation toward poetry, Socrates says that "we should put the poets aside and converse direct with each other, testing the truth and our own ideas" (348a4-6). Finally, immediately after Protagoras expresses the hesitation about hedonism noted above,

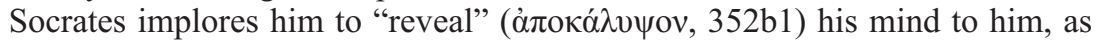
a patient would reveal his body to a doctor (thereby also bringing to mind Socrates' earlier claim that only a "physician of the soul" would know what is good for his students).

Indeed, Protagoras' willingness to dissimulate and hide his views is one of the distinctive features of his character in the dialogue. ${ }^{23}$ It is one that appears even in his final comments of the dialogue: "Socrates, I praise your enthusiasm and the way you find your way through an argument." The word "praise" has a special significance in the Protagoras. Prodicus earlier distinguishes praise ( $\dot{\pi} \alpha \mathbf{v \varepsilon \tau i v ) ~ f r o m ~ e s t e e m ~ ( \varepsilon ن ̉ \delta о к ц \varepsilon i ̃ v ) . ~ W h e r e a s ~ t h e ~ l a t t e r ~ " i s ~ g u i l e l e s s l y ~ i n h e r e n t ~}$ in the souls of the listeners," he says, "praise is all too often merely a deceitful verbal expression" (337b). Similarly, Socrates later speaks of those who force themselves to "praise" others against their own will $(346 a-b)$. The repeated emphasis on the potential for deceit in praise, combined with Protagoras' willingness to conceal his true thoughts, suggests that the sophist's "praise" of Socrates is one final sign of his insincerity. ${ }^{24}$ All of this shows that there may be a discrepancy between the views Protagoras professes openly in the dialogue and the views he genuinely holds, whether consciously or not. ${ }^{25}$ If that is the case, then we cannot conclude from his initial hesitation about hedonism that it is not his real view.

23. It is one that Plato clearly wants to contrast, moreover, with Protagoras' openness is advertising himself as a sophist. Protagoras states that he refuses to "disguise" ( $\pi \rho \circ \alpha \alpha \lambda v ́ \tau \varepsilon \sigma \theta \alpha \mathrm{l}, 316 \mathrm{~d} 6)$ his art as those in ancient

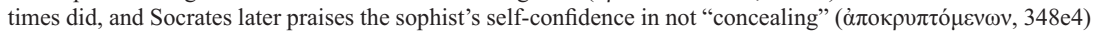
his wisdom as others do, but rather "proclaiming" ( also a contrast between Protagoras' eagerness to publicize his talents and the true Spartan philosophers described

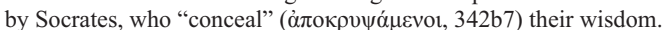

24. A further point, in connection with $334 \mathrm{a}-\mathrm{c}$ and n. 12 above, is that Plato contrasts poikilon speech such as sophistry and rhetoric with speech that is straightforward and candid. When characters in the dialogues ask Socrates what he means by something, he often responds, "Nothing complicated [poikilon]" (e.g., at Cra. 393d6; Grg. 491d10; Meno 75e5). The Athenian Visitor of the Laws similarly states that he will speak clearly and "without being complicated [poikillon]" (863e5-6). Finally, Alcibiades reports, "The lights were out; the slaves had left; and it seemed to me that I needed not to be evasive [poikillein], but to speak freely and tell him my thoughts" (218b9-c1). Poikilon speech, such as that delivered by Protagoras, is thus associated in Plato with prevarication and lack of clarity.

25. Goldberg $(1983,278)$ similarly concludes that "Socrates only resorted to the elaborate indirection ... because Protagoras, after several appeals, refused to reveal himself." Sesonske (1963, 74-76) also notes the duplicity of Protagoras' character, but does so largely on the basis of the Great Speech. 
Finally, the text indicates that Protagoras ultimately accepts the hedonistic identification of the good with pleasure. Significantly, at the start of their discussion he tells Socrates that if the claim that pleasure and the good are identical ends up seeming reasonable, then they will agree with each other (351e). ${ }^{26}$ Then, in the scene immediately following Socrates' defense of hedonism and the supremacy of knowledge, Socrates says to the sophists, "Now, I ask you, Hippias and Prodicus, as well as Protagoras - this is your argument too-to say whether you think what I say is true or false" (358a1-4). Socrates reports that they all thought what he said was "marvelously true." 27 Whatever initial reluctance Protagoras may have had about accepting the identity of goodness and pleasure, it is clear that he ultimately endorses it. Despite the sophist's unwillingness to share his thoughts, Socrates in the end "reveals" who Protagoras really is.

\section{Protagoras the PedDler}

What is Plato's aim in suggesting that Protagoras and his Man-Measure Doctrine are tied to hedonism? The answer, I believe, has to do with the concern that motivated Socrates' conversation with Protagoras in the first placenamely, his worry that Protagoras might be a mere merchant of ideas with no knowledge of what is truly good or bad for the soul. Note that this issue is a theme that runs throughout the dialogue and connects Socrates' early warning to Hippocrates to the later discussion of hedonism: Socrates initially draws on a medical analogy concerning what makes the body healthy or ill in order to introduce the idea that teachings can make a soul healthy or ill; Protagoras' speech about the good provides a list of what is good and healthy in one context but bad and sickening in another; and finally, Socrates establishes hedonism by way of a line of questioning in which Protagoras accepts the reduction of goodness and badness, along with health and illness, to painfulness and pleasurableness. ${ }^{28}$ My suggestion, then, is that Plato's association of the sophist with hedonistic values is intended to draw the reader's attention to Protagoras' inadequacy as an educator, and to the fact that he does not really possess the knowledge he promises. This happens, I take it, in two ways - the first perhaps more subtle, and the second more obvious and direct.

To begin with, the final discussion with Protagoras draws attention to the shortcomings of the sophist's signature Man-Measure doctrine. One of the crucial turning points of Socrates' arguments in the dialogue's final section is his account of the deceptive effect that appearances have on pleasure: they

26. It may also be significant that it is actually Protagoras himself, not Socrates, who explicitly introduces the strongest and clearest statement of hedonism into the text. Socrates initially asks whether living pleasantly suffices to live well, which certainly suggests that he is raising the question of hedonism, but he then says only that he wants to inquire whether pleasure is $a$ good; it is Protagoras who replies that they should investigate whether pleasure and good are the same at $351 \mathrm{e}$.

27. Some commentators - e.g., Grube 1933, 205; Sesonske 1963, 77; Sullivan 1961, 22-23 — suggest, partly on the basis of this passage, that the Protagoras represents all the sophists as implicitly hedonistic, an interpretation to which I am sympathetic.

28. The allusion to the earlier medical analogy is amplified by Protagoras' reference to фó $\rho \mu \alpha \kappa \alpha$ at 334a4 Coby $(1987,85)$ notes that "this enumeration of the variety of goods recalls Socrates' earlier account of the sophist as a merchant of nourishments." 
can make remote, future pleasures and pains seem smaller and less significant than they really are and immediate pleasures seem larger and more significant than they really are. Hence the power of appearance "often makes us wander all over the place in confusion, often changing our minds about the same things and regretting our actions and choices with respect to things large and small" (356d4-8). What is required in order to overcome the illusory effects of appearances is knowledge, which distinguishes how things appear from how they truly are. With Protagoras' approval on behalf of the Many, therefore, Socrates is able to drive a wedge between appearance and reality — precisely the distinction that Plato takes the Man-Measure doctrine to be centrally committed to denying.

Although Plato does not bring these implications for Protagoras' doctrine to the surface, there are reasons for thinking they underlie his presentation of the material. The first is that the line of objection to the Man-Measure doctrine implied by the final argument of the Protagoras is one that is advocated explicitly in the Theaetetus. In the course of his extended critique of Protagoras' view in the Theaetetus, Plato makes it clear that he takes the Protagorean position to have the most prima facie credibility in cases of immediate perceptual experience. ${ }^{29}$ Socrates affirms, "The theory would stand firm most successfully in the position which we sketched out for it in our attempt to bring help to Protagoras. I mean the position that most things are for the individual what they seem to him to be; for instance, warm, dry, sweet, and all this type of thing" (171d9-e3). Likewise, he tells Theodorus that "so long as we keep within the limits of that immediate present experience of the individual which gives rise to perceptions and to perceptual judgments, it is more difficult to convict [each man's judgments] of being untrue" (179c2-5). Significantly, Socrates explicitly classifies pleasure and pain as perceptions in the Theaetetus, alongside others such as sight, hearing, and feeling cold (156b-c). He suggests, for instance, that whereas wine both appears and is pleasant and sweet to a healthy man, it might appear and be bitter and unpleasant to the same man when he is sick (159c-160b). Presumably, Plato considers it plausible to think that if something feels pleasurable to a man, then it really is pleasurable for him at that time. Indeed, in the Philebus, Socrates concedes that it cannot be denied to those who are experiencing pleasure that they are experiencing it. While some pleasures are "true" pleasures and others "false" ones, they all count as pleasure, and "that which takes pleasure, whether it is rightly pleased or not, can obviously never be deprived of really taking pleasure" (37b2-3). While Plato finds it patently absurd to suppose that goodness is whatever it seems to be, then, he takes Protagoreanism about immediate pleasure more seriously, and he even accepts infallibility with respect to judgments that one is currently experiencing pleasure.

Socrates goes on to argue, however, that even if one grants to Protagoras the claim that present perceptual experiences are infallibly veridical, his doctrine will be unable to hold up concerning anticipated future perceptual experiences. Even if we concede to Protagoras, that is, that if a man now feels

29. Fine $(1998,220)$ and Reshotko $(1994,143)$ make similar points. 
warm or pleased, then he is warm or pleased, we cannot plausibly concede that if a man thinks he will be warm or feel pleasure at some time in the future, he always will be warm or feel pleasure at that time (178a-e). Even when it comes to something as plausibly subjective as pleasure, therefore, Protagoras' position ultimately proves indefensible when it comes to questions of whether, and from what sources, one will derive pleasure beyond the present moment. It is clear, then, that Plato takes considerations about the future- and the potential for error in judging and estimating future perceptual experiences- to be decisive in showing the failure of the Man-Measure doctrine. The fact that Socrates appeals to an argument of precisely this sort to drive a wedge between appearance and reality in the Protagoras, therefore, suggests that Plato is fully aware of the implications of that argument and likely intends for the reader to recognize them as well. ${ }^{30}$

An even more striking consideration in favor of this interpretation is the fact that Socrates refers to the knowledge that overcomes the deceptive power of

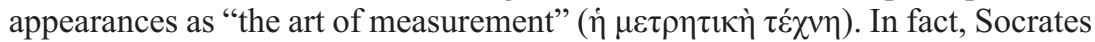
emphasizes this phrase: it is repeated eight times in just over one Stephanus page (356d-357e). This is surely a thinly veiled allusion on Plato's part to Protagoras" view that man is the "measure" ( $\mu \varepsilon \dot{\tau} \tau \rho$ v) of all things, and one that Plato's contemporary readers could hardly have missed. ${ }^{31}$ It is, moreover, a rather biting allusion: Protagoras is forced to concede, using the distinctive terminology of his own philosophical view, that how things appear to a man is not, after all, the "measure" of how they really are.

If this reading is correct, then by invoking hedonism, Plato is able to show that Protagoras' doctrine fails even in the case of something that might otherwise be taken to be a paradigmatically subjective form of value: pleasure. There may be a further implication, though. Plato clearly thinks that the Man-Measure doctrine is in tension with Protagoras' claims to possess knowledge and be capable of educating people. In the Theaetetus Socrates suggests that if whatever an individual judges or perceives is true for him, then no man can claim authoritative wisdom over others, and Protagoras cannot be serious when he advertises himself as a teacher (161d-162a). The idea is that (at most) either the Man-Measure doctrine is true or Protagoras deserves the fees he charges for education, but not both. In the Protagoras the sophist is implicitly faced with this very dilemma: Socrates' distinction between appearance and reality undermines the sophist's own doctrine, but in order to deny the distinction and defend his view, Protagoras would have to concede that he does not possess unique knowledge that distinguishes him from other men. Plato's Protagoras

30. Two further points of contact between the two dialogues are relevant: (1) In the Theaetetus Socrates comment, "No one would have paid large fees for the privilege of talking with [Protagoras] if he had not been in the habit of persuading his pupils that he was a better judge than any fortune-teller-or anyone else - about what was going to be and seem to be in the future" (178e9-179a3). This is, of course, precisely what the art of measurement promises to accomplish in the Protagoras. (2) In the Protagoras Socrates identifies the art of measurement as our "salvation" ( $\sigma \omega \tau \eta \rho i ́ \alpha, 357 \mathrm{a} 6$; cf. 356d3, e1, e4, e6, e8) from the ruinous effects of appearances. Similarly, in the Theaetetus Socrates argues that ordinary people look to those who possess knowledge as their "salvation" ( $\left.\sigma \omega \tau \eta \dot{\rho} \rho \varsigma_{\varsigma}, 170 \mathrm{~b} 1\right)$ during times of distress.

31. Vlastos (1956, xvii) comments, "What can this 'power of appearance' be but an indirect reference to the appearance-is-reality doctrine in its bearing on the good life?" See also Coby 1987, 153. 
makes a clear choice: he tells Socrates that "it would be shameful indeed for me above all people to say that wisdom and knowledge are anything but the most powerful forces in human activity" (351d1-3), and he concedes the claims that undermine his view without objection. Faced with the possibility of losing clients, in other words, Protagoras is unwilling to defend his own signature doctrine. It is a subtle implication, but a clear one: Protagoras is more concerned with profit than with truth and philosophical integrity. ${ }^{32}$

The dialogue's association of Protagoras with hedonism draws attention to another way in which the sophist fails as an educator-one which is more direct. Socrates' warning to Hippocrates early in the dialogue had assumed that a good educator must know what makes the soul healthy or ill. From Plato's point of view, though, pleasure is clearly not what makes the soul healthy or ill. In being tied to hedonism in the ways that he is, therefore, Protagoras is bound to promote a false conception of the good. To begin with, in order to "sell" himself to the Many, we have seen, Protagoras must advertise himself as the sort of educator who can advance their pleasure-loving ambitions. This is precisely what he does in the dialogue's final scenes, where he allows the knowledge he peddles to be identified with the pleasure-maximizing art of measurement. In an earlier scene, moreover, Plato suggests a much more sinister consequence of Protagoras' reliance on the approval of the Many. Recall that when Socrates presses Protagoras to explain what he has to offer his students, the sophist promises to teach "sound deliberation" ( $\varepsilon$ ủßov $\lambda i ́ \alpha)$. In a later passage, also while answering on behalf of the Many, Protagoras acknowledges that people act temperately by acting unjustly, and that acting temperately means "deliberating well" (cũ

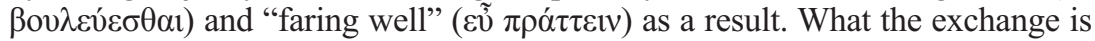
leading toward is the conclusion that people achieve what is good and beneficial for themselves by acting unjustly. Hence what it means to "deliberate well," from the point of view of the Many upon whom Protagoras depends for his living, is to achieve good things through injustice. The implication is that in order to market his teachings successfully, Protagoras would have to teach not the justice he had promised in his Great Speech, but rather skillful injustice. Protagoras never allows the conclusion or its implications to be drawn, however: he interrupts Socrates' questioning with his spontaneous speech on goodness at 334a-c.

The problem, however, is not just that Protagoras is professionally bound to appeal to the self-interested and hedonistic tendencies of the Many. As discussed above, his own understanding of what is noble and good seems actually to be informed by those tendencies, as well as by his own character and philosophical commitments. The sophist himself is clearly unaware of his affinity to the crowd, however. He considers himself superior to them and actually expresses contempt for the Many on a number of occasions throughout the dialogue. ${ }^{33}$ Despite his scorn, however, Protagoras ends up, as we have seen,

32. Thus I do not find Moser and Kustas' $(1966,113)$ argument persuasive that the fact that Protagoras accepts Socrates' distinction between appearance and measurement shows that there are no traces of Protagorean relativism in the text. Cf. remarks in Grube 1933, 206; Vlastos 1956, xx.

33. When Socrates suggests that they investigate the common view that knowledge is sometimes "dragged around" by pleasure, for example, the sophist responds, "Why is it necessary for us to investigate the opinion of

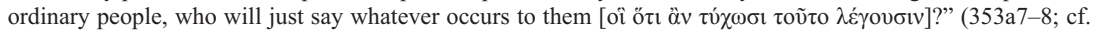


enthusiastically accepting the hedonistic position of the Many. Protagoras, then, is not merely their neutral spokesperson for the sake of argument. Rather, he conceals himself behind their views, but in the end turns out himself to hold the very same position as the Many he makes a show of disdaining. Protagoras cannot possibly teach the Many, therefore, because the views he himself holds and espouses merely mimic their own misguided prejudices. ${ }^{34}$

Early in the dialogue Protagoras criticizes other teachers who abuse young men by "leading [ó $\gamma \circ \nu \tau \varepsilon \varsigma]$ them back, against their will, into the sorts of subjects they have escaped from at school, teaching them arithmetic, astronomy, geometry, music, and poetry." A young man who studies with him, he says, will learn "only what he has come for" (318e1-5). Later Socrates confronts the view of the Many that a man with knowledge can be "led" (áó $\mu \varepsilon v o \varsigma, 355 b 1)$ and overwhelmed by pleasure. Knowledge, Socrates argues, is the sort of thing that necessarily leads and rules in an individual. If Protagoras truly possessed knowledge, it seems, then he would lead his students, rather than being led by them to teach whatever pleases them. Instead, with his money-loving and hedonistic proclivities, the sophist turns out to be ignorant of what is good for the souls of his students, though he continues to advertise his teachings all the same: in the end Protagoras the hedonist is a peddler of ideas, but not an educator.

Wayne State University

317a-b). It is significant, perhaps, that in the Apology Socrates characterizes his own speech, in contrast to the ornate rhetoric of his accusers, in precisely the terms with which Protagoras derides the many: Socrates' defense

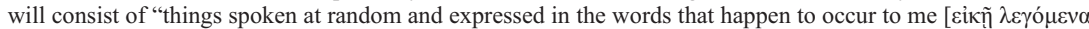

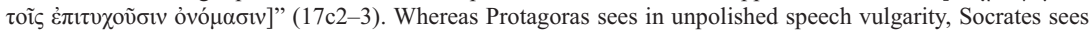
the kind of artless self-expression that Protagoras refuses to offer him.

34. There are other considerations related to the final section of the dialogue that suggest Protagoras is ineffective as an educator: (1) Tht. 178d-e makes the point that whereas Protagoras may be an authority on what sorts of public speeches will have a persuasive effect on audiences in the future, it is the professional cook - not even individuals themselves - who is best able to predict what will be pleasant to people in the future. This suggests that Protagoras is not the right person to teach the pleasure-maximizing Art of Measurement that the Many seek. (2) Even if Protagoras did possess pleasure-maximizing knowledge as the Many understand it, there are good reasons for doubting that such knowledge would truly provide "salvation" in life. This point is explored in Coby 1987, 159; Dimas 2008, 277; Dyson 1976, 43; and Ferrari 1990, 124-25. (3) A number of commentators have argued that the dialogue's focus on courage is due to the fact that Plato considers courage to be the virtue that Protagoras is especially unqualified to teach. This is the focus of Duncan's (1978) treatment of the text and is also addressed in Klosko 1980, 321; McCoy 1998, 29, 37; and Wolz 1967, 216. To their arguments I would like to add one further point. We have seen that Protagoras, with his money-loving inclinations and lifestyle, resembles the oligarchic individual of the Republic. Significantly, Socrates argues there that oligarchs are uniquely inept at fighting in war, and precisely because of their love of wealth (552d-e).

\section{LITERATURE CITED}

Adam, A. M., and J. Adam. 1957. Platonis Protagoras. Cambridge.

Bentley, R. K. 2003. Ruling Oneself: Platonic Hedonism and the Quality of Citizenship. Polis 20: 85-107.

Burnyeat, Myles. 1990. Introduction. In The “Theaetetus of Plato,” trans. M. J. Levett, 1-241. Indianapolis.

Clark, Justin. 2012. The Strength of Knowledge in Plato's Protagoras. Ancient Philosophy 32: 237-55.

Coby, Patrick. 1987. Socrates and the Sophistic Enlightenment. London. 
Cooper, John M., ed. 1997. Plato: Complete Works. Indianapolis.

Crombie, I. M. 1962. An Examination of Plato's Doctrines. Vol. 1. London.

Dimas, Panos. 2008. Good and Pleasure in the Protagoras. Ancient Philosophy 28: 253-84.

Dodds, E. R. 1959. Plato: “Gorgias.” Oxford.

Duncan, Roger. 1978. Courage in Plato's Protagoras. Phronesis 23: 216-28.

Dyson, M. 1976. Knowledge and Hedonism in Plato's Protagoras. JHS 96: 32- 45.

Ebert, Theodor. 2003. The Role of the Frame Dialogue in Plato's Protagoras. In Plato's "Protagoras": Proceedings of the Third Symposium Platonicum, ed. Aleš Havlíček and Filip Karfik, 9-20. Prague.

Ferrari, G. R. F. 1990. Akrasia as Neurosis in Plato's Protagoras. In Proceedings of the Boston Area Colloquium in Ancient Philosophy IV, ed. John Cleary and Daniel Shartin, 115-40. Lanham, Md.

Fine, Gail. 1998. Plato's Refutation of Protagoras in the Theaetetus. Apeiron 31.3: 201-34.

Frede, Michael. 1992. Introduction. In Plato: "Protagoras," trans. Stanley Lombardo and Karen Bell, vii-xxxiv. Indianapolis.

Goldberg, Larry. 1983. A Commentary on Plato's “Protagoras.” New York.

Graham, Daniel W. 2010. The Texts of Early Greek Philosophy. Vols. 1-2. Cambridge.

Grote, George. 1888. Plato and the Other Companions of Sokrates. Vol. 2. London.

Grube, G. M. A. 1933. The Structural Unity of the Protagoras. CQ 27: 203-7.

Guthrie, W. K. C. 1969. A History of Greek Philosophy. Vol. 3. Cambridge.

Hackforth, R. 1928. Hedonism in Plato's Protagoras. CQ 22: 39-42.

Irwin, Terence. 1977. Plato's Moral Theory. Oxford. 1995. Plato's Ethics. Oxford.

Kerferd, G. B. 1949. Plato's Account of the Relativism of Protagoras. Durham University Journal 42: $20-26$.

- 1953. Protagoras' Doctrine of Justice and Virtue in the Protagoras of Plato. JHS 73: $42-45$.

Klosko, George. 1980. On the Analysis of Protagoras 351B-360E. Phoenix 34: 301-22. 1986. The Development of Plato's Political Thought. New York.

McCoy, Marina Berzins. 1998. Protagoras on Human Nature, Wisdom, and the Good: The Great Speech and the Hedonism of Plato's Protagoras. Ancient Philosophy 18: 21-39.

Moser, S., and G. L. Kustas. 1966. A Comment on the "Relativism" of the Protagoras. Phoenix 20: 111-15.

Nussbaum, Martha. 1986. The Fragility of Goodness. Cambridge.

Reshotko, Naomi. 1994. Heracleitean Flux in Plato's Theaetetus. History of Philosophy Quarterly 11: 139-61.

Rudebusch, George. 1989. Plato, Hedonism, and Ethical Protagoreanism. In Essays in Ancient Greek Philosophy, vol. 3, Plato, ed. John Anton and Anthony Preus, 27-40. Albany.

Russell, Daniel. 2005. Plato on Pleasure and the Good Life. Oxford.

Santas, Gerasimos. 1966. Plato's Protagoras and Explanations of Weakness. Philosophical Review 75 : 3-33.

Schiller, F. C. S. 1908. Plato or Protagoras? Mind 17: 518-26.

Sesonske, Alexander. 1963. Hedonism in the Protagoras. Journal of the History of Philosophy 1: 73-79.

Sullivan, J. P. 1961. The Hedonism in Plato's Protagoras. Phronesis 6: 10-28.

Taylor, A. E. 1927. Plato: The Man and His Work. London.

Taylor, C. C. W. 1976. Plato: “Protagoras.” Oxford.

Versenyi, Laszlo. 1962. Protagoras’ Man-Measure Fragment. AJP 83: 178-84.

Vlastos, Gregory. 1956. Introduction. In Plato: “Protagoras, ” trans. Benjamin Jowett, rev. Martin Ostwald, vii-lviii. Indianapolis. 1969. Socrates on Acrasia. Phoenix 23: 71-88. 
Weiss, Roslyn. 1989. The Hedonic Calculus in the Protagoras and the Phaedo. Journal of the History of Philosophy 27: 511-29.

2006. The Socratic Paradox and Its Enemies. Chicago.

Wolfsdorf, David. 2006. The Ridiculousness of Being Overcome by Pleasure: Protagoras 352B1358D4. Oxford Studies in Ancient Philosophy 31: 113-36.

Wolz, Henry. 1967. Hedonism in the Protagoras, Journal of the History of Philosophy 5: 205-17. Woolf, Raphael. 2002. Consistency and Akrasia in Plato's Protagoras. Phronesis 47: 224-52.

Zeyl, Donald. 1980. Socrates and Hedonism: Protagoras 351b-358d. Phronesis 25: 250-69. 
QUERY TO THE AUTHOR

No Query. 